DOI: https://doi.org/10.32839/2304-5809/2021-11-99-65

УДК 355.531 .3

Біліченко В.В.

Дніпропетровський державний університет внутрішніх справ

\title{
ДОСЛІДЖЕННЯ ЕФЕКТИВНОСТІ ВИКОНАННЯ ЗАВДАНЬ У МАЛИХ ТАКТИЧНИХ ГРУПАХ
}

Анотація. У даній статті висвітлюються основні аспекти ефективності застосування тактики малих тактичних груп. Окрім цього, зазначаються особливості розподілення ролей в таких малих тактичних групах та роз'яснюеться кут відповідальності, який закріплюеться за кожним членом групи. Також зазначаються негативні моменти, з якими можна зіткнутися у практичній діяльності під час виконання завдань у малих тактичних групах та наведені діеві методи вирішення вищевказаних проблемних аспектів. Окрім цього, охарактеризовано поняття малих тактичних груп, їх кількісний та функщіональний склад. Крім того, зазначаються найбільш поширені випадки проведення операцій за допомогою малих тактичних груп.

Ключові слова: малі тактичні групи, екстремальна ситуація, поліцейський, професійна підготовка, аналіз ситуації, особиста безпека.

Bilichenko Valeriy

Dnipropetrovsk State University of Internal Affairs

\section{INVESTIGATION OF THE EFFECTIVENESS OF TASK PERFORMANCE IN SMALL TACTICAL GROUPS}

Summary. This article highlights the main aspects of the effectiveness of the tactics of small tactical groups. In addition, the specifics of the distribution of roles in such small tactical groups are noted and the angle of responsibility assigned to each member of the group is explained. There are also negative aspects that can be encountered in practice when performing tasks in small tactical groups and effective methods for solving the above problems. In addition, the concept of small tactical groups, their quantitative and functional composition are characterized. In addition, the most common cases of operations with the help of small tactical groups are noted. Outlines the main cases of involvement in operations small tactical groups, in particular, internal and external inspection of the building, the release of hostages or even the search for offenders for operational information. It is noted that conducting tasks as part of small tactical groups significantly increases the efficiency of a particular task. Also, it should be noted that small tactical groups are usually used not only in risk situations. the risk can be both known and unknown, so the use of tactics to perform tasks in small tactical groups is the key to successful operations. The conclusion summarizes the importance of small tactical groups in the elimination of tasks associated with known and unknown risk. It is characterized that the work in small tactical groups is based on self-understanding and preliminary distribution of roles among all persons of such tactical group. Only due to the presence of appropriate symbols, communication and camouflage means it is possible to bring the operation to a logical conclusion and perform all the necessary tasks for which such an operation is performed. The main directions of improving the activities of small tactical groups with further improvement of both legislative and practical parts are indicated. Keywords: small tactical groups, extreme situation, policeman, professional training, situation analysis, personal safety.

$\Pi^{2}$ остановка проблеми. В сучасних умовах коли криміногенна ситуація в Україні зазнала значних змін та зросла в динаміці, коли прояви тероризму в остатні роки, змушують серйозно задуматися над питаннями щодо протидії таким явищам. Майже завжди працівники поліції під час виконання своїх професійних завдань входять до складу малих тактичних груп (зведений загін, мобільна група, група захоплення, група прикриття), кількість та якість виконання тактичних шикувань та пересувань, в екстремальних ситуації дае змогу підвищити рівень особистої безпеки та особового складу груп. Ефективний аналіз ситуації, в екстремальних умовах, дае змогу швидше зоріентуватись у подальших діях, щодо припинення протиправних дій, а це зумовлено у правильній та професійній підготовці поліцейського. Малі тактичні групи використовуються майже завжди в надзвичайних та екстремальних ситуаціях. Особовий склад таких груп піддаеться більшому ризику, а ефективність групи передбачає насамперед відсутність травмованих та загиблих при проведені тактичних дій.

Аналіз останніх досліджень. Проблематикою ефективності та покращення роботи малих тактич- них групах займалося багато вітчизняних вчених, зокрема: В.В. Пасічник, Т.В. Синовіцька, В.Н. Зарицький, Л.А. Харкевич, Т.В. Шевченко, М.О. Котелюх. Але, слід зауважити, що питання ефективності на достатньому рівні не було висвітлено.

На наш погляд, очевидною $е$ необхідність дослідити ефективності малих тактичних груп, виокремити недоліки виконання завдань та що перешкоджає, що є причиною несвоєчасного вирішення поставлених завдань та порушення зазначеної тактики в діях при вирішенні проблем.

Метою статті є дослідження ефективності дій малих тактичних груп та виокремлення можливих шляхів вирішення проблеми пов'язаної 3 діяльністю груп в екстремальних ситуаціях.

Виклад основного матеріалу. Мала тактична група (далі - МТГ) це так звана тактична одиниця, яка складаеться 3 двох та більше поліцейських, що виконують одну спільну задачу, спеціальну операцію дотримуючись одного спільного плану, із застосуванням спеціальних засобів, вогнепальної зброї, спеціальних транспортних засобів, як правило кожен з так званого підрозділу виконуе свою фуннццію під час про- 
ведення операції тим самим забезпечує особисту безпеку та безпеку побратима. Слід зазначити, тактичні групи використовуються, як на відкритому просторі так і в приміщеннях, будівлях для виконання покладених на них завдань [1, с. 272].

Під організації проведення спеціальних операцій недостатньо уваги приділяються використанню малих оперативних груп. Обсяг необхідних спеціальних знань, умінь та навичок, якими повинні володіти співробітники, що залучені до проведення спеціальних операцій, залежить від багатьох фракторів: пора року, час доби, погодні умови, географрія місця проведення, та інше. Велику роль відіграє кількість залучених груп та особового складу, а це в свою чергу залежить від об'єму задач, від керівника групи, головним елементом спільної співпраці є зв'язок в середині групи та між групами та єдина система управління, чітке встановлення ділянок відповідальності.

Малі тактичні групи можуть формуватися як на постійній основі так і на тимчасовій та виконують свої завдання в межах вирішення одніеї тактичної задачі. Тактичні групи в якій задіяно мала чисельність особового складу можуть вирішувати такого типу тактичні задачі, як: звільнення заручників, транспортного засобу, будинків, аеропортів, пошук, знешкодження, затримання конвоювання злочинців, охоронна публічного порядку, забезпечення громадської безпеки [2, с. 77].

Головним аспектом $є$ те ,що під час виконання задач в малих тактичних групах в екстремальних ситуаціях, наприклад під час звільнення будинку, слід ощінити ситуащію та продумати можливі версії в ситуації, що можу скластись також в ситуаціях під час спостереження або розвідки. Забезпечення особистої безпеки працівників поліцї це конституційне право правоохоронців, «Людина, іiї життя i здоров'я, честь і гідність, недоторканність і безпека визнаються в Україні найвищою соціальною цінністю». Тому способи та засоби захисту людей, особливо при виконанні службових обов'язків на робочих місцях є завжди актуальними, а з урахуванням підвищеної безпеки для правоохоронців, ці питання необхідно вирішувати у першу чергу. Малі тактичні групи використовуються майже завжди в надзвичайних та екстремальних ситуащіях. Особовий склад таких груп піддається більшому ризику, а едективність групи передбачає насамперед відсутність травмованих та загиблих при проведені оперативних дій. Дослідження та удосконалення способів зниження рівня травматизму правоохоронщів при виконанні тактичних дій виконувалися в рамках науково-дослідної роботи на тему «Заходи щодо забезпечення особистої безпеки персоналу та підвищення його профресійного рівня», яка виконуеться за заявкою відділу з нагляду за охороною праці головного штабу МВС України.

Бойові шикування малих тактичних груп відносяться до базових навичок Національної поліції та інших підрозділів для виконання своїх завдань та має особливі спеціальні тобто властиві лише для них якості та підготовку, а саме напращьовані рефлекси, здібності, що необхідні групам для виконання завдань, для яких необхідно дотримуватись всіх вимог при підготовці. Слід зазначити що до основних видів шикування відносять: лінія, колона, клин, ромб, стріла та скорпіон. Кожен вид тактичного шикування має як свої переваги так і недоліки. Але хотіли б зазначити, що найбільша кількість по- зитивних критерїв мать шикування клин та ромб. Ці два шикування не $є$ найкращими в усіх ситуаціях вони є універсальними. Відстань та вибір шикування напряму залежить від особливостей місцевості, від кількості особового складу, яка задіяна для виконання задачі, від ощінки ситуащії в екстремальній ситуації, що дає змогу зоріентуватися у виборі та ефрективності застосування групи [3, с. 127-130].

Особовий склад тактичних груп повинен містити в собі такі якості, як стійкість, витривалість, незламність перед труднощами та швидка реакція на зміну обстановки, взяти за приклад навчання на базі Дніпропетровського державного університету внутрішніх справ, а саме в забезпеченні публічної безпеки та порядку масових заходів за Скандинавською моделлю, а саме для спецпризначенців України та Іспанії, цим самим продемонстрували профресійність та якість роботи в малих тактичних групах для боротьби 3 перешкодами, які можуть спіткати на шляху виконання задач.

Основні недоліки підготовки співробітників $€$ незадовільна тактико-спеціальна і бойова готовність до профресійної діяльності. Проаналізовано процес профресійної, в тому числі вогневої та спеціальної фрізичної, психологічної підготовки працівників поліції. На сьогодні профпідготовка працівників НП вимагає впровадження нових форм і методів роботи, які сприяли б формуванню професійно-важливих якостей і підвищення рівня виконання пращівниками поліщї оперативно-службових завдань. Визначено психологічні фрактори правомірного застосування працівниками поліції вогнепальної-силового впливу. Кількісний та якісний склад малих бойових груп залежить від багатьох складових, який було теоретично проаналізовано та експериментально обгрунтовано в роботі.

Дослідження теми МТГ та їх використання в службовій діяльності правоохоронця передбачає критеріальний підхід, а саме:

1. Кількісний критерій, що передбачає в собі кількість противників, кількість особового складу МТГ та геометричний критерій.

2. Просторовий критерій, полягає в навичках групи та постановці.

3. Тактичний критерій, що містить в собі розстановку сил та засобів, бойове шикування, тактику дій в різноманітних екстремальних ситуаціях.

Поняття «ефективне виконання службово-бойових задач» полягає в тому, що застосовується лише за умови коли наявні та виконанні всі критерії. Саме при наявності всіх критеріїв можлива ефективна робота малих тактичних груп та якісне виконання своїх задач [4, с. 109-111].

У даний час набуває особливого значиння підготовка МТГр у короткі терміни. Отже, при ухваленні рішення про їх використання для виконання бойових задач буде витрачатися менший час на підготовку, ніж під час планової підготовки. Для цого необхідно розробити спеціальні програми підготовки застосуванню до тих завдань, які мають бути МТГ, з урахуванням театру військових дій та ймовірного характеру дій супротивника. З'являється потреба у виробленні напрямів щодо вдосконалення рекомендацій МТГр для виконання поставлених задач відповідно до призначення у збройних конфліктах:

- проводити підготовку МТГр до виконання бойових завдань з урахуванням особливостей театра військових дій у будь-яку пору року та діб, а також ймовірного характеру дій супротивника; 
- особливу увагу у підготовці приділити злагодженості дій штатних та наданих підрозділів МТГр, їх взаємодії при виконання бойового завдання;

- впровадити у систему підготовки МТГр тренажери та інформаційні навчальні системи, що дозволить покращити якість підготовки, при цьому суттєво скоротити час та матеріальні витрати;

- покращувати індивідуальну підготовку всіх посадових осіб командного складу за керівництва підрозділами 3 метою реалізації единого інформаційного простору з метою застосування автоматизованої системи управління військами;

- поліпшити бойове, технічне, тилове та медичне забезпечення для виконання бойових завдань.

В результаті проведеного дослідження можна зробити наступний висновок: в цілому розвиток способів застосування МТГр у локальних війнах і збройних конфрліктах показало, що вони залишаються однією з найважливіших складових бойової могутності військових частин постійної готовності у Збройних силах України. До основних тенденцій застосування батальйонних тактичних груп у збройних конфрліктах можна віднести «підвищення тактичної автономності підрозділів, розширення характеру бойових завдань у різних видах бою, швидке зосередження на вирішальному напрямку ведення бойових дій при проведенні оперативного маневру» [8, с. 30-33].

Висновок. У підсумку варто зазначити, що едективність дій малих оперативних груп, має велике значення у професійній діяльності, а також у сьогоденні. Ситуащія в країні має напружений характер, тим самим натякає про повну готовність до екстреного прийняття рішень у ситуащіях та повну готовність підрозділів до можливого конфлікту.

На даний момент справа йде вже не про надання більшої уваги особистої безпеки співробітників правоохоронних органів, а про екстрені заходи в Україні з залученням юридичних, економічних, технічних, організаційних заходів.

Існуюча в даний час тенденція до зростання злочинності в країні вимагає нового підходу до профресійної підготовки особового складу органів внутрішніх справ, а особливо особистого складу малих бойових груп. В результаті аналітичних та експериментальних досліджень були отримані наступні основні висновки:

- для протидії організованій злочинності та екстремістським проявам необхідне редрормування системи профресійної підготовки;

- для активної протидії злочинності необхідно більш інтенсивно удосконалювати систему профресійної підготовки оперативних підрозділів, а саме малих груп (захоплення, прикриття, штурмових);

- зростає роль індивідуальної підготовки кожного бійця групи;

- кількісний склад малих груп залежить від виду виконуваних службово-оперативних задач, ступеню небезпеки, кількості злочинців, інтенсивності фрізичного та психологічного навантаження (для поліцейських підрозділів склад групи знаходиться у діапазоні від 3 до 8 осіб);

- у подальшому необхідно розробити основні критерії готовності особового складу малих бойових груп;

- необхідно розробити методику профресійної підготовки особового складу малих бойових груп;

- запровадити до критеріїв ефрективності дій малих бойових груп - показник безпеки (відсутність втрат та постраждалих після виконання службово-бойових задач);

- едективність дій малих бойових груп залежить від ступеню опрацювання кожної ситуації, які можуть скластися під час виконання задачі; - вид бойового шикування залежить від особливостей обстановки;

- проблема удосконалення дій малих бойових груп, методика їх підготовки, способи підвищення дій таких підрозділів, визначення їх готовності потребують подальших глибоких досліджень.

Ми вважаємо, що виконання зазначених критеріїв, дає змогу вплинути на ефективність роботи та захист своеї безпеки та безпеки інших осіб, адже зазначенні поради можуть врятувати життя.

Запровадження закордонного досвіду в країні надає можливість більш ширше відкрити тактичні дії, моделювання ситуацій буде позитивно впливати на оцінку ситуацій та швидке прийняття рішення в екстрених ситуаціях, цим самим тактичний досвід буде мати своє місце під час вирішення тактичних завдань.

\section{Список літератури:}

1. Василенко В. В., Дзюба В. М., Окунський О. Ю., Пилипів Б. І. Вогнева підготовка : навч. посіб. (з метод. рек.). Київ : Вид. Паливода А. В., 2003. 272 с.

2. Зарицкий В. Н., Харкевич Л. А. Общая тактика : учеб. пособие. Тамбов : Изд-во Тамб. гос. техн. ун-та, 2007.

3. Шевченко Т.В. Критеріальні дослідження ефективності дій малих оперативних груп. Збірник тез доповідей VIII Науково-практичної Конфберениї̈ «Наукове забезпечення службово-бойової діяльності Національної гвардї̈ України», 30 березня 2017 р. Харків : НАНГУ, 2017. С. 127-130.

4. Шевченко Т. В. Щодо розуміння поняття «екстремальні умови» в діяльності національної поліції. Актуальні проблеми вітчизняної юриспруденцї̈. Дніпро : ДНУ ім. Олеся Гончара, 2016. С. 109-111

\section{References:}

1. Vasylenko V. V., Dzyuba V. M., Okunsky O. Y., Pylypiv B. I. (2003) Vohneva pidhotovka: navch. posib. (z metod. rek.) [Fire training: textbook. way. (with method. rec.)]. Kyiv: Ed. Palivoda A.V.

2. Zaritsky V. N., Kharkevich L. A. (2007) Obshchaia taktyka: ucheb. posobye [General tactics: textbook allowance]. Tambov: Tamb Publishing House. state tech. university.

3. Shevchenko T. V., Koteliukh M. O. (2007) Kryterialni doslidzhennia efektyvnosti dii malykh operatyvnykh hrup [Criteria research of efficiency of actions of small operative groups]. Collection of abstracts of the VIII Scientific and Practical Conference "Scientific support of service and combat activities of the National Guard of Ukraine" [Collection of abstracts of the VIII Scientific and Practical Conference "Scientific support of service and combat activities of the National Guard of Ukraine"] March 30, Kharkiv: NANGU.

4. Shevchenko T. V. (2016) Shchodo rozuminnia poniattia «ekstremalni umovy» v diialnosti natsionalnoi politsii [On understanding the concept of "extreme conditions" in the activities of the national police]. Scientific collection "Actual problems of domestic jurisprudence [Scientific collection "Actual problems of domestic jurisprudence"]. Dnipro: DNU Oles Gonchar. 